\title{
COASTAL COMMUNITIES' WILLINGNESS TO PAY FOR MANGROVE ECOTOURISM IN MARUDU BAY, SABAH, MALAYSIA
}

\author{
FAZILAH MUSA* ${ }^{* 1,2}$, NORASHIKEEN MOHD FOZI ${ }^{1}$ AND DIANA DEMIYAH MOHD \\ HAMDAN $^{1,2}$ \\ ${ }^{1}$ Faculty of Science and Natural Resources, Universiti Malaysia Sabah, UMS Street, 88400, Kota Kinabalu, Sabah, Malaysia. \\ ${ }^{2}$ UMS SIMSEA Research Group, Universiti Malaysia Sabah, UMS Street, 88400, Kota Kinabalu, Sabah, Malaysia.
}

*Corresponding author: fazilah.musa@ums.edu.my

Submitted: 1 September 2019 Accepted: 20 January 2020

http://doi.org/10.46754/jssm.2020.06.013

\begin{abstract}
The revenue contribution of mangrove forests to Malaysia's economic growth is usually associated with fishing. Generally, fishing is one of the main sources of income for coastal communities, and mangroves are found in abundance in coastal areas. Nowadays, mangrove forests have become a very significant product in the tourism sector. It enhances Malaysia's economy through increasing the earnings of local communities and creating more job opportunities. The potential of mangrove forests as a dynamic ecotourism industry is being rapidly capitalized in many parts of Malaysia. However, the economic benefits of mangrove forests in the tourism sector have not been used to its fullest because of the non-existent market for this resource. This study aims to determine the willingness to pay (WTP) of the coastal communities in Marudu Bay, Sabah, to develop their mangrove areas as an ecotourism destination. To achieve this, the study engages in the contingent valuation method (CVM). Questionnaires were distributed to 400 respondents from five selected coastal villages, asking them whether they are willing to pay for five bid prices, RM5, RM10, RM15, RM20 or RM30, for mangrove ecotourism conservation. Logistic regression was applied to estimate the mean WTP by using three different types of logit models. Results indicate that the estimated mean for each WTP model is as follows: Model 1 (the full model) at RM12.96/person/year, Model 2 (the restricted model) at RM16.08/ person/year and Model 3 at RM25.68/person/year, respectively. The coastal communities' responses of their WTP were based on the bidding prices and their socio-demographic variables. The majority of them had the WTP because they were confident that the conservation of mangroves promotes sustainable ecotourism and can improve community income, hence would better their livelihoods for generations to come. .
\end{abstract}

Keywords: Willingness to pay, contingent valuation method, mangrove conservation, coastal communities.

\section{Introduction}

The mangrove ecosystem has many natural resources for coastal communities in the form of forest and fishery produce. It provides food and is a source of livelihood for them (Mojiol et al., 2016). In terms of income, many coastal communities worldwide earn below the poverty line if they depend only on fishing. However, they can tap into the resources of the mangrove ecosystem around their villages to supplement their household income (Nyein Aye et al., 2019). Nevertheless, over the years, mangrove degradation has become rampant due to rapid physical development and unsustainable management of the forests. Several studies have shown that mangrove biodiversity has also been affected (Datta et al., 2012; Malik et al., 2015; Adegboyega et al., 2019; Sofian et al., 2019). Malaysia has the fifth-largest mangrove forest in the world (Spalding et al., 2010) and, remarkably, Sabah is blessed with the largest and vast of such area. The state's coast in Borneo is laden with mangrove forests that are notable for their luxuriant flora and fauna species and rich biodiversity (Faridah Hanum et al., 2012; Zakaria \& Rajpar, 2015). The diversity of marine resources has helped Malaysia maintain its position as a famous destination among international tourists and has enhanced local coastal communities' standard of living 
(Masud et al., 2017). Nowadays, the mangrove ecosystem is well known for providing natural resources, such as wood and seafood, that help increase the socioeconomic development of communities living near mangrove areas. The Kilim Geopark in Langkawi and the Ramsar wetlands in Johor are examples of popular mangrove ecotourism destinations in Malaysia that have successfully generated income for their local communities (Fazilah et al., 2013; Jaafar et al., 2015). In Malaysia, ecotourism is one of the sectors undergoing rapid development as it is recognized for contributing towards overall economic growth (Jaafar \& Maideen, 2012).

Community-based ecotourism (CBE) is an initiative that aims to alleviate poverty in rural areas by encouraging the active participation of local communities in ecotourism activities. $\mathrm{CBE}$ include mangrove forest development that emphasizes the sustainable ecotourism destination approach (Mohamad Zabidi et al., 2013). It is stressed that CBE development requires social capital as a significant key factor in strengthening cooperation and coordination among local communities to ensure its success (Hussin et al., 2014; Liu et al., 2014; Situmorang, 2018). The involvement of coastal communities in the establishment and management of mangrove resources can develop the confidence for long-term ecosystem sustainability (Hakim et al., 2017; Masud et al., 2017). On the other hand, poor participation of local communities may cause unwise behaviour towards the sustainable use of natural resources. In addition, the management of mangrove forests should adhere to sustainable ecotourism concepts that can benefit local communities and sustain future generations (Törn et al., 2007; Arkwright \& Kaomaneng, 2018). Normally, the capital needed for mangrove rehabilitation projects is high and it should not compromise or burden the low-income residents of the mangrove ecosystem (Susilo et al., 2017). Thus, other parties, like non-governmental organizations (NGOs) and the government, should chip in and play their part. One of the main attractions of mangroves for visitors is the biodiversity of the flora and fauna (Ramli et al.,
2018). It is not refutable that on site, mangrovebased ecotourism supports the biodiversity conservation and socioeconomic development of local communities (Hakim et al., 2017).

Notably, Sabah has the potential to develop mangrove ecotourism destinations due to diversity in the forests that contain various marine life, besides the unique cultures of local communities and amazing landscapes (Fazilah et al., 2013). In regard to improvements in the socioeconomic status of rural communities in Sabah, studies have shown that the ecotourism industry, spearheaded by the government through the provision of essential facilities and infrastructure, and collaborations with local stakeholders had directly benefitted them (Mohamad Zabidi et al., 2013; Goh, 2015). Indeed, other related studies contend that the existence of the mangrove ecosystem is crucial in generating a multitude of sustainable socioeconomic developments, such as environmental, economic, and social benefits, to the coastal communities (Kathiresan, 2012; Sofian et al., 2019). This is supported by another study that states as the recipients of the mangrove ecosystem, coastal communities depend on sustainable mangrove forest resources management to meet their needs (Eddy et al., 2017).

However, it has been said that the economic benefits of mangrove resources are poorly quantified in terms of their monetary value due to the lack of awareness and the absence of markets for mangrove forests (Balmford et al., 2002; Carandang et al., 2013). Hence, conservation programs undertaken by the local authorities to encourage and increase the willingness of coastal communities to pay from the economic prospective will contribute significantly to improving public participation (Hamuna et al., 2018). Thereby, it can strengthen the potential of coastal community-based ecotourism while sustaining the mangrove ecosystem. Therefore, this study is initiated to estimate the economic value of mangrove forests as ecotourism destinations through the local communities" "willingness to pay" (WTP). 
Marudu Bay, Sabah, is chosen as the study area and the methodology used to gauge WTP is the contingent valuation method (CVM).

\section{Materials and Methods}

\section{Study Area}

This study was conducted in Kota Marudu, Sabah, Malaysia (6 53 ' 13.6" N; $116^{\circ} 49^{\prime} 31$ " E), which was $130 \mathrm{~km}$ away from Kota Kinabalu, the state capital. The Kota Marudu mangrove forests were located in Marudu Bay, with a total area of 12,893 ha, and it had been gazetted as a Mangrove Forest Reserve Class V for both production and protection purposes under the Forestry Department management (Mohamad Zabidi et al., 2013). Marudu Bay's mangrove forests spanned across Kudat, Kota Marudu and Pitas districts (Faridah Hanum et al., 2012). Nine villages were identified as having the potential to become ecotourism destinations in Kota Marudu (Fazilah et al., 2013). However, only five were selected for this study. They were Kampung Tanjung Batu, Kampung Tambun, Kampung Tigaman, Kampung Tanah Merah and Kampung Taritipan. These villages were chosen based on their proximity to Marudu Bay.

\section{Data Collection}

The contingent valuation method (CVM) was a method that could estimate the economic value for a variety of non-market goods (Carson, 2001), like individuals' WTP for a hypothetical situation (Chen \& Jim, 2010). The CVM of this study was done via distributing questionnaire surveys directly to the selected coastal communities of Kota Marudu. The sample size of each village was determined by using Slovins's formula (Tejada \& Punzalan, 2012) at a $95 \%$ confidence level. Respondents were identified using the random sampling method. Questionnaires were randomly distributed to 400 respondents of the five villages ( 80 questionnaires for each village) from August to October 2017. The questionnaire was designed to collect data on the villagers' WTP for mangrove ecotourism and their willingness to participate in the conservation of mangroves. The questionnaire was divided into four sections: Part A: General knowledge about ecotourism and mangrove forests; Part B: Coastal communities' perception on the importance of mangroves ecotourism; Part C: Their WTP for coastal communities' ecotourism; and Part D: Respondents' demographic and socioeconomic profiles. The questionnaire was prepared in Malay because it was the common language of the villagers living in Kota Marudu, comprising diverse ethnic groups. Five bid prices were used in this study: RM5, RM10, RM15, RM20 and RM30.

\section{Statistical Analysis}

Logistic regression was applied to estimate the mean WTP (Hanemann, 1984) and three different types of the logit models were used to determine the factors of the WTP (Chen \& Jim, 2010). The first model was the mean WTP with demographic and socio-economic variables. The second model was the same, except that some variables from the first model were excluded. The third model was calculated by using bid prices only. The bid prices, and demographic and socio-economic variables were obtained by using the correlation analysis method i.e. to determine the factors that influenced the WTP of respondents. The general model in this study is in equation 1 .

Prob $($ Yes $)=f($ Bid price, race, age, marital status, number of household, job, side job and income) 
The logit model is as in equation 2:

$$
\begin{aligned}
& \log \left[\frac{\operatorname{Prob}(\text { Yes })}{1-\operatorname{Prob}(Y e s)}\right]=a+\beta 1 \mathrm{Bid}+\beta 2 R A C i+ \\
& \beta 3 \mathrm{AGEi}+\beta 4 \mathrm{MSi}+\beta 5 \mathrm{NOHi}+ \\
& \beta 6 J O B i+\beta 7 S J O B i+\beta 8 I N C i+\varepsilon i \\
& \text { where: } \\
& \text { Prob(Yes) = Probability of accepting the } \\
& \text { bid price } \\
& 1 \text { - Prob (Yes) = Probability of not accepting } \\
& \text { the bid price } \\
& \mathrm{i}=\text { Index of observation } \\
& \alpha, \beta_{1}, \beta_{2}, \ldots, \beta_{12}=\text { Parameters }
\end{aligned}
$$

$\begin{array}{ll}\varepsilon i & =\text { Error } \\ \mathrm{BID} & \text { Bid }(0: \text { No, } 1: \text { Yes }) \\ \mathrm{RAC} & \text { Race }(0: \text { others, } 1: \text { Bumi- } \\ & \text { putera }) \\ = & \text { Age }(\text { year }) \\ \mathrm{AGE} & \text { Marital status }(0: \text { others, } 1: \\ \mathrm{MS} & \text { Married }) \\ \mathrm{NOH} & \text { Number of household }(0: \text { oth- } \\ & \text { ers, } 1: 5-7 \text { people }) \\ = & \text { Job }(0: \text { others, } 1: \text { Self-em- } \\ \text { JOB } & \text { ployed }) \\ = & \text { Side job }(0: \text { Yes, } 1: \text { No) } \\ \mathrm{SJOB} & \text { Income }(\mathrm{RM}) \\ \mathrm{INC} & \end{array}$

Therefore, the estimated probability will be in equation 3 .

$\log \left[\frac{\operatorname{Prob}(\text { Yes })}{1-\operatorname{Prob}(\text { Yes })}\right]=\frac{1}{1+e^{a+\beta 1 B i d+\beta 2 R A C i+\beta 3 A G E i+\beta 4 M S i+\beta 5 N O H i+\beta 6 J O B i+\beta 7 S J O B i+\beta 8 I N C i+\varepsilon i}}$

The mean WTP can be obtained based on the following equation 4 :

Mean $W T P=\frac{\ln \left(1+e x p^{\alpha+\beta i X i}\right)}{-B i}$

where:

$\alpha=$ Constant

$B i=$ Coefficient of variable

$X i=$ Mean of the respective explanatory

$\beta i=$ Coefficient of estimate on the bid price

\section{Results and Discussion}

\section{Respondents' Profile}

Bajau communities mostly live in the west and east coast of Sabah and practised Islam (Halina Sandera, 2013; Mojiol et al., 2016). Majority of the respondents from the selected villages in Kota Marudu were Muslims of the Bajau and Suluk ethnicity. They were categorized as "Bumiputera" and were mostly self-employed, depending on fisheries as their main source of income and food. Their education status is listed in Table 1.

Only a few respondents obtained tertiary education, which enabled them to work in public or private sectors with earnings that surpassed the poverty threshold. Most of the other respondents only had an education up to secondary school. This was due to their poor background. Hence, most respondents had to work to support their families during their childhood or start working right after completing secondary school (Aziz \& Iskandar, 2013; Mohamad Zabidi et al., 2013). Meanwhile, for those who worked in the public and private sectors, they still had to look for jobs to support their families, even after retiring from their jobs. Therefore, mangroves provided natural resources that were sought after by these people to supplement their household necessities.

Many communities in Kudat who live near mangrove areas earned below the poverty line and relied on the forest to supplement their income (Mojiol et al., 2016; Nyein Aye et al., 2019). A previous study found that the average gross income for communities in Kota Marudu was RM713.61 per month (Mohamad Zabidi et al., 2013). Even five years later, their household income and socioeconomic status remained unchanged (Table 1). More than half of the respondents were in the middle-age group of 30 to 59 , which was significantly higher than the younger age groups. Generally, the younger generation would have to find work elsewhere. 
It is believed that the development of mangrove ecotourism could provide job opportunities to people in this age group and make them stay in their villages. The phenomena of rural-urban migration could be curbed, and the younger generations could participate actively in the ecotourism activities at their villages. This was in line with the ecotourism sustainable development goals as the younger generation was more adept at using mass media technologies in marketing strategies (Basyuni et al., 2018). Consequently, the estimation of the WTP might differ based on socioeconomic and demographic factors, as well as the motivational factor and general context of the biodiversity conditions (Chen \& Jim, 2010).

Table 1: Respondents' socio-economic and demographic profile

\begin{tabular}{|c|c|c|c|}
\hline Variables & & Frequency & Percentage (\%) \\
\hline \multirow[t]{2}{*}{ Gender } & Male & 205 & 51.00 \\
\hline & Female & 195 & 49.00 \\
\hline \multirow[t]{4}{*}{ Ethnic } & Bumiputera & 377 & 94.25 \\
\hline & Malay & 11 & 2.75 \\
\hline & Chinese & 3 & 4.40 \\
\hline & Others & 7 & 1.75 \\
\hline \multirow[t]{4}{*}{ Religion } & Islam & 383 & 95.75 \\
\hline & Christian & 10 & 2.50 \\
\hline & Buddhist & 5 & 1.25 \\
\hline & Others & 2 & 0.50 \\
\hline \multirow[t]{4}{*}{ Age } & $\leq 18$ years & 48 & 12.00 \\
\hline & $19-29$ years & 61 & 15.25 \\
\hline & $30-59$ years & 204 & 51.00 \\
\hline & $\geq 60$ years & 87 & 21.75 \\
\hline \multirow[t]{4}{*}{ Education Status } & No Formal Education & 56 & 14.00 \\
\hline & Primary School & 136 & 34.00 \\
\hline & Secondary School & 180 & 45.00 \\
\hline & University/College & 28 & 7.00 \\
\hline \multirow[t]{3}{*}{ Marital Status } & Single & 61 & 15.25 \\
\hline & Married & 316 & 79.00 \\
\hline & Divorced/Widowed & 23 & 5.75 \\
\hline \multirow[t]{3}{*}{ No. of Household } & $1-4$ person & 153 & 38.25 \\
\hline & $5-7$ person & 183 & 45.75 \\
\hline & $\geq 8$ person & 64 & 16.00 \\
\hline \multirow[t]{5}{*}{ Monthly Income } & $\leq \mathrm{RM} 1,000$ & 299 & 74.75 \\
\hline & RM1, 001 - RM2, 000 & 65 & 16.25 \\
\hline & RM2, 001 - RM3, 000 & 14 & 3.50 \\
\hline & RM3, 001 - RM4, 000 & 13 & 3.25 \\
\hline & $\geq \mathrm{RM} 4,001$ & 9 & 2.25 \\
\hline \multirow[t]{3}{*}{ Job } & Public / Private Sector & 34 & 8.75 \\
\hline & Self employed & 313 & 78.25 \\
\hline & Retired & 52 & 13.00 \\
\hline
\end{tabular}




\section{WTP for Mangrove Conservation}

Mangroves provided various economic products, and this explained why early settlements were usually established near the forests (Mojiol et al., 2016; Nyein Aye et al., 2019). This ecosystem could continuously sustain its endowment if the natural habitats were not overexploited and the general environment was not degraded (Arkwright \& Kaomaneng, 2018). Although many villagers living in mangrove areas were not well educated and had low income, they could still pass down their technical skills, techniques or indigenous knowledge to their children on how to depend and defend the ecosystem (Chen \& Jim, 2010; Hakim et al., 2017). This study found that the main factor driving their WTP was their desire to ensure that their younger generation could continuously enjoy the resources of the mangroves (Table 2). It was evidenced from the survey that most of them had WTP for the conservation of mangroves (Table 2). They were even willing to contribute some capital to ensure the sustainability of the mangrove ecosystem. This was primarily because they realized how highly dependent, they were on the mangrove ecosystem for their future.

By conserving the mangroves, future generations could generate income and sustain food resources (Amjad \& Jusoff, 2007). It was confirmed that Marudu Bay's mangroves had the potential to be developed into a lucrative community-based ecotourism destination that would enhance the socioeconomic status in the study areas (Mohamad Zabidi et al., 2013). The mangroves, with its rich and biodiverse properties, could attract both local and international tourists to Marudu Bay (Faridah Hanum et al., 2012; Zakaria \& Rajpar, 2015). Thus, ecotourism activities here would provide more job opportunities to the local communities while minimising the migration of the younger generation to urban areas. However, from the survey, the coastal communities were in favour of the ecotourism activities being self-managed, rather than being controlled by outsiders (Table 2 ). A previous study reiterated that the active participation of local communities was a social capital that is a significant key factor in the successful establishment of a community-based ecotourism project (Situmorang, 2018). This was because the locals had better understanding and more knowledge on the peculiarities of the mangrove ecosystem around their villages, and therefore, could meaningfully help with conservation activities (Chen \& Jim, 2010; Hakim et al., 2017). This study found that the locals were willing to work with outsiders to provide guidance, skills training, and ecotourism management expertise, especially by non-governmental organisations. They also welcomed government agencies to provide the budget for infrastructure and overall development to kickstart the industry (Abdullah et al., 2014; Goh, 2015).

Table 2: Reasons for WTP and not WTP for mangrove conservation at Marudu Bay

\begin{tabular}{lc}
\hline Statement & Percentage (\%) \\
\hline Reasons for WTP & 6.25 \\
Conservation of mangroves & 33.46 \\
Contribution towards ecotourism development & 60.29 \\
Mangroves can be enjoyed by the community in the future & \\
Reasons for not WTP & 39.06 \\
Cannot afford to pay & 35.94 \\
Willing to pay but not this amount & 5.47 \\
Willing to pay but in other ways & 19.53 \\
Others & \\
\hline
\end{tabular}




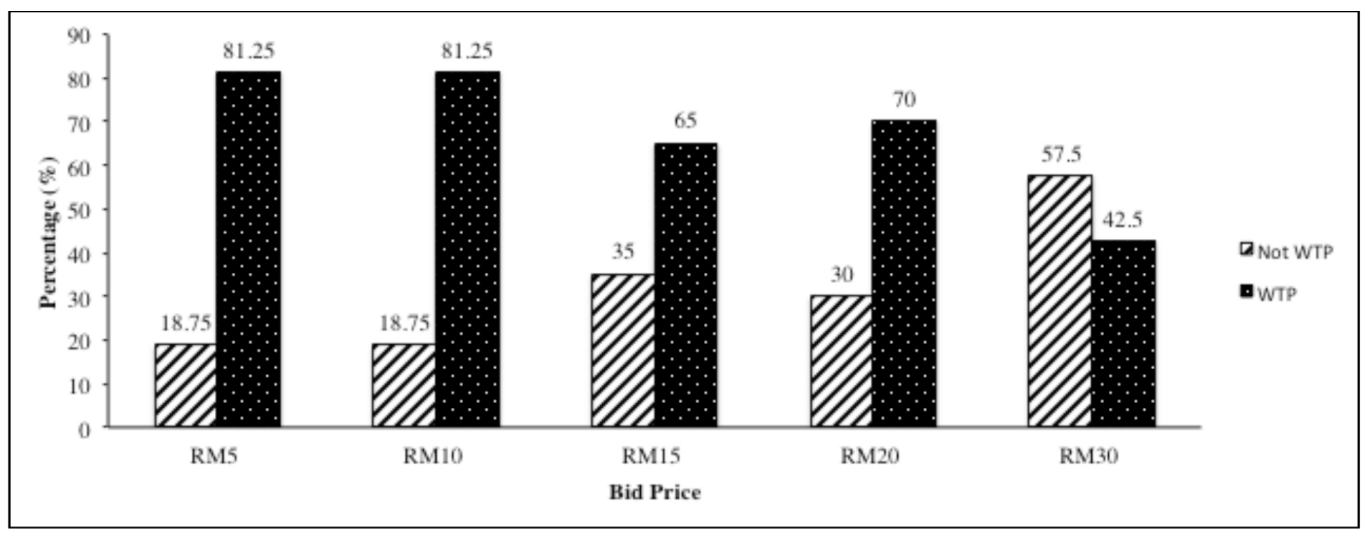

Figure 1: WTP for mangrove conservation based on bid prices in Marudu Bay, Sabah

The purpose of introducing the bid prices of RM5, RM10, RM15, RM20 and RM30 in this study was to conveniently estimate the WTP for mangrove conservation in monetary terms. Based on Figure 1, it showed that the lower the bidding value, the higher the respondent's WTP. And because of the affordability factor, the bid price of RM30 was found to have the lowest subscription, where $57.5 \%$ did not have the WTP. Most coastal communities were aware that the mangroves' rich biodiversity could contribute to ecotourism development (Nazaruddin et al., 2013; Ramli et al., 2018). Another study showed that even those earning below the poverty line were also interested in the ecotourism sector as they knew that it could generate income and were willing to support mangrove forest conservation to avoid environmental pollution (Abdullah et al., 2013).

Meanwhile, this study found that the main reason why some respondents were not supportive of WTP was mostly because they could not afford to contribute to communitybased mangrove ecotourism purposes (Table 2). Most of the Kota Marudu coastal communities worked as traditional fishermen and earned less than RM1,000 per month (Table 1). Another reason found for those who did not have WTP was because they assumed that ecotourism activities would hinder fishery activities in Marudu Bay (Table 2). Nonetheless, another research stressed that community-based ecotourism not only enhanced the socioeconomic status of coastal communities, but it could indirectly ensure that mangrove forests were managed sustainably (Basyuni et al., 2018). This was proven by a similar ecotourism project i.e. the Matang Mangrove Forest Reserve, which was considered the best mangrove management in the world (Goessens et al., 2014), and had become an iconic ecotourism industry in Malaysia (Fazilah et al., 2013).

\section{Estimated Mean WTP}

For this study, the coefficient on bid price variables were found to be significant (Chen \& Jim, 2010) and it was expected to have a negative sign, while other variables had a positive sign (Yeo et al., 2013). The negative sign of the bid price revealed that the respondents did not have WTP, or there would be an increase of the "No" answer if the bid price was higher than the contingent valuation question. Meanwhile, it was stated that the variable had a direct relationship with WTP (Yeo et al., 2013) as the mangrove conservation showed a positive sign, and vice versa.

The estimated mean WTP among the coastal communities for mangrove conservation in Marudu Bay was determined by using the logit model. Model 1 (full model) involved eight variables (race, age, marital status, number of household, job, side job, income), whereas Model 2 (restricted model) excluded race, age and marital status and lastly, Model 3 involved 
the bid prices only (Table 3). Results indicated that the estimated mean WTP for Model 1 (full model), Model 2 (restricted model) and Model 3 were RM12.96/person/year, RM16.08/person/year and RM25.68/person/ year, respectively. These results showed that the coastal communities' WTP towards communitybased ecotourism was largely influenced by the bid prices, and their socio-economic and demographic factors.

Results also indicated that Model 2 was the most suitable to express WTP among the coastal communities for mangrove conservation in Kota Marudu. The mean WTP for this model was determined by the bid price, number of households, job, side job and income. These factors were found to play an important role in influencing the ecotourism involvement among the coastal communities. Meanwhile, a previous study noted that the money factor, such as stakeholder's income, could affect the WTP in forest conservation activities among communities (Norjumawati \& Ang, 2016). However, another study believed the communities' high living standards had made them respond positively towards environmental issues (Shen \& Saijo, 2008).

\section{Conclusion}

The real economic value of mangrove forests as an ecotourism destination in Marudu Bay could be estimated through the coastal communities' WTP in monetary terms. The results of the three models showed that the WTP of coastal communities were very much influenced by their socio-economic and demographic factors, as well as affordability. Another contribution of this study was that the estimation of the mean WTP could give vital information to the state government and the local authorities in allocating funds for the conservation of mangrove forests, as well as for the development of the ecotourism industry of the mangrove forests in Marudu Bay. In the long run, this industry would benefit not only the coastal communities of Marudu Bay but interject revenues to the local authorities and the state of Sabah as well. Above all, this study showed that the mangrove ecosystem's sustainability needed mutual involvement of stakeholder communities, NGOs, and the government.

\section{Acknowledgements}

The authors wish to extend their appreciation to the Sabah Forestry Department and all survey repondents in Kota Marudu, Sabah, for their cooperation and provision of invaluable data for this study.

Table 3: Results of the logit model for mean WTP

\begin{tabular}{lcccccc}
\hline \multirow{2}{*}{ Variable } & \multicolumn{2}{c}{ Model 1 } & \multicolumn{2}{c}{ Model 2 } & \multicolumn{2}{c}{ Model 3 } \\
\cline { 2 - 7 } & B & Mean & $\boldsymbol{\beta}$ & Mean & $\boldsymbol{\beta}$ & Mean \\
\hline Bid Price & -0.125 & 3 & -0.125 & 3 & -0.125 & 3 \\
Race & -0.87 & 0.94 & - & - & - & - \\
Age & 0.178 & 2.82 & - & - & - & - \\
Marital Status & -0.373 & 0.79 & - & - & - & - \\
No. of Household & 0.002 & 1.78 & 0.002 & 1.78 & - & - \\
Job & -0.224 & 0.78 & -0.224 & 0.78 & - & - \\
Side Job & -0.361 & 0.32 & -0.361 & 0.32 & - & - \\
Monthly Income & -0.241 & 4.58 & -0.241 & 4.58 & - & - \\
Constant & 3.169 & 3 & 3.169 & 3 & 3.169 & 3 \\
\hline Mean WTP & RM 12.96 person/year & RM 16.08 person/year & RM 25.68 person/year \\
\hline
\end{tabular}




\section{References}

Abdullah, K., Said, A. M., \& Omar, D. (2014). Community-based conservation in managing mangrove rehabilitation in Perak and Selangor. Procedia-Social and Behavioral Sciences, 153, 121-131.

Abdullah, M., Awang Noor, A. G., Faridah Hanum, I., Zakaria, M. H., \& Hin, W. Y. (2013). Local community participatory process and intervention procedure in mangrove ecotourism of Marudu Bay, Sabah. Pertanika Journal Tropical Agriculture Science, 36, 173-180.

Adegboyega, S. A., Oloukoi, J., Olajuyigbe, A. E., \& Ajibade, O. E. (2019). Evaluation of unsustainable land use/land cover change on ecosystem services in coastal area of Lagos state, Nigeria. Applied Geomatics, 11(1), 97-110.

Amjad, A., \& Jusoff, K. (2007). Mangrove Conservation through Community Participation in Pakistan: The Case of Sonmiani Bay. International Journal of System Applications, Engineering \& Development, 4(1), 75-81.

Arkwright, D., \& Kaomaneng, I. S. (2018). Mangrove ecotourism development on Kakaralamo Island North Halmahera: Community perception, participation and development strategies. IOP Conference Series: Earth and Environmental Science, 175(1), 012232. doi, 10.1088/17551315/1/012232.

Aziz, R. A., \& Iskandar, S. (2013). Working children and knowledge of right to education: A study of child labour in Sabah, Malaysia. Asian Social Science, 9(8), 2233.

Balmford, A., Bruner, A., Cooper, P., Costanza, R., Farber, S., Green, R. E., Jenkins, M., Jefferiss, P., Jessamy, V., Madden, J., Munro, K., Myers, N., Naeem, S., Paavola, J., Rayment, M., Rosendo, S., Roughgarden, J., Trumper, K., \& Turner, R. K. (2002) Economic reasons for conserving wild nature. Science, 297(5583), 950-953.
Basyuni, M., Bimantara, Y., Siagian, M., Wati, R., Slamet, B., Sulistiyono, N., Nuryawan, A., \& Leidonad, R. (2018). Developing community-based mangrove management through eco-tourism in North Sumatra, Indonesia. IOP Conference Series: Earth and Environmental Science, 126, 012109. doi, 10.1088/1755-1315/126/1/012109.

Carandang, A. P., Camacho, L. D., Gevaña, D. T., Dizon, J. T., Camacho, S. C., de Luna, C. C, Pulhin, F. B., Combalicer, E. A., Paras, F. D., Peras, R. J. J., \& Rebugio, L. L. (2013). Economic valuation for sustainable mangrove ecosystems management in Bohol and Palawan, Philippines. Forest Science and Technology, 9(3), 118-125.

Carson, R. T., Flores, N. E., \& Meade, N. F. (2001). Contingent valuation: controversies and evidence. Environmental and Resource Economics, 19(2), 173-210.

Chen, W. Y., \& Jim, C. Y. (2010). Resident motivations and willingness-to-pay for urban biodiversity conservation in Guangzhou (China). Environmental Management, 45(5), 1052-1064.

Datta, D., Chattopadhyay, R. N., \& Guha, P. (2012). Community based mangrove management: a review on status and sustainability. Journal of Environmental Management, 107, 84-95.

Eddy, S., Ridho, M. R., Iskandar, I., \& Mulyana, A. (2017). Community-based mangrove forests conservation for sustainable fisheries. Jurnal Silvikultur Tropika, 7(3), 42-47.

Faridah-Hanum, I., Kudus, K. A., \& Saari, N. S. (2012). Plant diversity and biomass of Marudu Bay mangroves in Malaysia. Pakistan Journal of Botany, 44(Suppl. 2), 151-156.

Fazilah, M., Awang Noor, A. G., \& Abdullah, M. (2013). Enhancing the Quality of Life of Coastal Community through Ecotourism Development in Kota Marudu, Sabah. Prosiding Persidangan Kebangsaan Pertama Program Pemindahan Ilmu (KTP 
01) 21- 23 Ogos 2013 Bangi, Selangor (Program Pemindahan Ilmu - Kementerian Pendidikan Malaysia). p 948-957.

Goessens, A., Satyanarayana, B., Van der Stocken, T., Zuniga, M. Q., Mohd-Lokman, H., Sulong, I., \& Dahdouh-Guebas, F. (2014). Is Matang mangrove forest in Malaysia sustainably rejuvenating after more than a century of conservation and harvesting management? PLoS One, 9(8), e105069. doi, 10.1371/journal. pone. 0105069 .

Goh, H. C. (2015). Nature and community-based tourism (CBT) for poverty alleviation: A case study of Lower Kinabatangan, East Malaysia. Geografia-Malaysian Journal of Society and Space, 11(3), 42-52.

Hakim, L., Siswanto, D., \& Makagoshi, N. (2017). Mangrove conservation in East Java: The ecotourism development perspective. Journal of Tropical Life Science, 7(3), 277285.

Halina Sendera, M. Y. (2013). Cosmology and world-view among the Bajau: The supernatural beliefs and cultural evolution. Mediterranean Journal of Social Sciences, 4(9), 184-194.

Hamuna, B., Rumahorbo, B., Keiluhu, H., \& Alianto, A. (2018). Willingness to pay for existence value of mangrove ecosystem in Youtefa Bay, Jayapura, Indonesia. Journal of Environment Management and Tourism, 9(5), 907-915.

Hanemann, W. M. (1984). Welfare evaluation in contingent valuation experiments with discrete responses. American Journal of Agricultural Economics, 66(3), 332-341.

Hussin, R., Mohd Yassir, S., \& Kunjuraman, V. (2014). Potential of homestay tourism based on seaweed cultivation from the views of seaweed cultivators in district of Semporna Sabah, East Malaysia. SHS Web of Conferences, 12(01005), 1-11.

Jaafar, M., \& Maideen, S. A. (2012). Ecotourism-related products and activities, and the economic sustainability of small and medium island chalets. Tourism Management, 33(3), 683-691.

Jaafar, M., Nordin, A. O. S., Marzuki, A., \& Abdullah, S. (2015). Development of ecotourism products in Kilim Geopark based on tourist perceptions. Journal of Sustainability Science and Management, 10(1), 1-18.

Kathiresan, K. (2012). Importance of Mangrove Ecosystem. International Journal of Marine Science, 2(10), 70-89.

Liu, J., Qu, H., Huang, D., Chen, G., Yue, X., Zhao, X., \& Liang, Z. (2014). The role of social capital in encouraging residents' proenvironmental behaviours in communitybased ecotourism. Tourism Management, 41, 190-201.

Malik, A., Fensholt, R., \& Mertz, O. (2015). Mangrove exploitation effects on biodiversity and ecosystem services. Biodiversity and Conservation, 24(14), 3543-3557.

Masud, M. M., Aldakhil, A. M., Nassani, A. A., \& Azam, M. N. (2017). Community-based ecotourism management for sustainable development of marine protected areas in Malaysia. Ocean \& Coastal Management, 136, 104-112.

Mohamad Zabidi, H., Awang Noor, A. G., Abdullah, M., Fazilah, M., \& Mohd Fauzi, Z. (2013). The Potential of CommunityBased Ecotourism (CBE) of Mangrove Ecosystem in Kota Marudu, Sabah Prosiding Persidangan Kebangsaan Pertama Program Pemindahan Ilmu (KTP 01) 21-23 Ogos 2013 Bangi, Selangor (Program Pemindahan Ilmu - Kementerian Pendidikan Malaysia) pp. 958-966.

Mojiol, A. R., Guntabid, J., Lintangah, W., Ismenyah, M., Kodoh, J., Chiang, L. K., \& Sompud, J. (2016). Contribution of mangrove forest and socio-economic development of local communities in Kudat district, Sabah Malaysia. International 
Journal of Agriculture, Forestry and Plantation, 2, 122-129.

Nazaruddin, D. A., Armugam, K. M., Wahab, R., Muhamad Nor, A. N., \& Mohd Fauzi, N. (2013). Identification of natural resources and features for ecotourism purposes in the Kelantan Delta Area, Malaysia. International Journal of Sciences, 2, 63-70.

Norjumawati, S., \& Ang, K. H. (2016). Willingness to pay concept in natural mangrove conservation: a review. International Research Journal of Humanities and Social Science, 1(4), 102110.

Nyein Aye, W., Yali, W., Marin, K., Thapa, S., \& Tun, A. W. (2019). Contribution of mangrove forest to the livelihood of local communities in Ayeyarwaddy region, Myanmar. Forest, 10(5), 414. doi: 10.3390/ f10050414.

Ramli, F., Samdin, Z., Abd Ghani, A. N., \& Mohamad Kassim, M. R. (2018). Factors affecting user's perception towards conservation of biodiversity in Matang Mangrove Forest Reserve (MMFR), Perak, Malaysia. International Journal of Business and Society, 19(SI), 26-36.

Shen, J., \& Saijo, T. (2008). Reexamining the relations between socio-demographic characteristics and individual environmental concern: evidence from Shanghai data. Journal of Environmental Psychology, 28(1), 42-50.

Situmorang, R. O. (2018) Social capital in managing mangrove ecotourism by the Muara Bambai community. Indonesian Journal of Forestry Research, 5(1): 21-34.
Sofian, A., Kusmana, C., Fauzi, A., \& Rusdiana, O. (2019). Ecosystem servicesbased mangrove management strategies in Indonesia: a review. Aquaculture, Aquarium, Conservation \& Legislation, 12(1), 151-166.

Spalding, M., Kainuma, M., \& Collins, L. (2010). World atlas of mangroves. ITTO, ISME, FAO, UNEP-WCMC. UNESCO$M A B$ and UNUINWEH. London: Earthscan Publications Ltd. doi, 10(97818497), 76608.

Susilo, H., Takahashi, Y., \& Yabe, M. (2017). The opportunity cost of labour for valuing mangrove restoration in Mahakam Delta, Indonesia. Sustainability, 9(12), 2169. doi, $10.3390 /$ su9122169.

Tejada, J. J., \& Punzalan, J. R. B. (2012). On the misuse of Slovin's formula. The Philippine Statistician, 61(1), 129-136.

Törn, A., Siikamäki, P., Tolvanen, A., Kauppila, P., \& Rämet, J. (2007). Local people, nature conservation, and tourism in northeastern Finland. Ecology and Society, 13(1), 1-18.

Yeo, S. C., Awang Noor, A. G., \& Lee, P. C. (2013). The estimation of economic benefits of urban trees using contingent valuation method in Tasik Perdana, Kuala Lumpur. Pertanika Journal of Tropical Agricultural Science, 36(1), 99-114.

Zakaria, M., \& Rajpar, M. (2015). Assessing the fauna diversity of Marudu Bay mangrove forest, Sabah, Malaysia, for future conservation. Diversity, 7(2), 137-148. 